decision are so numerous and varied as to be impossible to calculate and reduce to any general rule.

The discussion in this comment has not considered the manner in which noclear-majority decisions should be cited. At best, it would appear that they should be used as precedent only after a careful analysis and evaluation which recognizes the absence of clear-majority agreement. This is sometimes done, but more often apparently disregarded. The difficulties inherent in the former inquiry and the dangers incident to the latter practice raise the further question of the propriety of handing down no-clear-majority decisions at all. Alternatively, it may be suggested that much can be done by the Court to indicate the points of agreement and disagreement in such cases. It is hoped that it will no longer be necessary to label them no-clear-majority decisions, but rather clear, no-majority decisions.

\title{
TAXATION OF MULTIPLE TRUSTS
}

The five-year throwback provision of the 1954 Internal Revenue Code has re-focused attention on an old problem ${ }^{1}$-use of a number of accumulating trusts which, as a result of the progressive rate structure, are each taxed at a lower rate than would be applicable if only a single trust were used..$^{2}$ Although avoidance of the additional surtax in this manner ${ }^{3}$ was possible long before the 1954 Code, prior to $1954^{4}$ it was possible to use a single accumulating trust, give

${ }^{1}$ Interest in the multiple trust problem reached a peak in the late 1930's as a result of a Congressional investigation. Consult Hearings before the Joint Committee on Tax Evasion and Avoidance, 75th Cong., 1st Sess. (1937). For discussion of the complexion of the problem at that time, consult Multiple Trusts and the Minimization of Federal Taxes, $40 \mathrm{Col}$. L. Rev. 309 (1940), and Paul, The Background of the Revenue Act of 1937, 5 U. of Chi. L. Rev. 41, 71-75 (1937).

2 Although statistical evidence of the use of multiple trusts is understandably unavailable, the attention the device has received suggests that it is highly popular among tax-planners. For example, the Wall Street Journal began a recent feature article on the effect of taxation on business and property planning with the following: "Sylvanus G. Felix is building a $\$ 3.5$ million, 17-story office building in Oklahoma City. He's not alone in this venture. Far from it. His co-entrepreneurs: 27 trusts (for the benefit of his children) and eight corporations (he's president of each one). Mr. Felix could eliminate a lot of bookkeeping by handling the project alone. But he'd rather not. By splitting the building's income among 36 taxpayers, he figures he'll cut total income taxes 'by more than 50\%.' " The Wall Street Journal, p. 1, col. 6 (Midwest ed., Jan. 5, 1956).

${ }^{3} \mathrm{~A}$ single taxpayer with no dependents receiving $\$ 100,000$ per year from personal services and $\$ 100,000$ ordinary income from investments pays approximately $\$ 156,000$ in taxes at present rates. If all the investment property were transferred and tased to a single trust, the saving would be approximately $\$ 22,000$ per year. Use of ten trusts would save an additional $\$ 41,000$ per year. The saving exists not only because the marginal tax rate is lower, but also because each trust receives a deduction for personal exemption. Int. Rev. Code $\$ 642(\mathrm{~b})$, 26 U.S.C.A. $\S 642(\mathrm{~b})(1954)$.

${ }^{4}$ Consult Aronsohn and Michaelson, Partnerships Estates and Trusts (Practicing Law Institute Fundamentals of Federal Taxation Series) 48-54 (1953 ed.), for an explanation of the 65-day and 12-month rules of Int. Rev. Code \$162, 26 U.S.C.A. \$162 (1939) as amended. 
the beneficiaries regular annual income distributions, and nevertheless retain a substantial part of the tax burden in the trust. ${ }^{5}$ The throwback rule, by forcing accumulations of trust income for long periods, ${ }^{6}$ deprives beneficiaries of regular income distributions unless a series of trusts, distributing in succession, is used.

The multiple trust problem has three aspects. First, the "accumulating trust" aspect: Because a single accumulating trust may be taxed as a separate entity, the grantor may use it to secure a substantial tax saving and yet the beneficiaries eventually will receive the income. Second, the "multiplication of entities" aspect: By using several accumulating trusts, the saving may be further increased as each trust will be taxed at a rate lower than the rate that would have been applicable to a single trust, though again the beneficiaries eventually will receive the income. Third, the "throwback avoidance" aspect: By arranging distributions from the several entities to come within the throwback rule exceptions, ${ }^{7}$ the beneficiaries may receive the equivalent of current income while the tax saving remains unimpaired.

The multiple trust problem may thus be approached on three levels. First, tax savings through use of a single accumulating trust might be eliminated by abolishing the trust as a taxpaying entity. Although this change might be desirable from the viewpoint of general tax policy, it will not be examined in this comment, for the consequences of the change are too drastic to justify its adoption solely to combat multiple trusts. The "throwback avoidance" aspect might be met by eliminating some or all of the throwback-rule exceptions. ${ }^{8}$ If all exceptions were eliminated so that every distribution of income or its equivalent would be taxable to the beneficiary whenever made, the single accumulat-

5 "[I]f the income of 1950 was distributed on March 8, 1951, and the income of 1951 was distributed on March 3,1952, then nothing was taxable to the beneficiary on account of 1950 income and only the 1951 income was taxable to the beneficiary. Hence by alternating the annual distributions on March 8 and March 3 of successive years the tax burden on half the trust income could still be shifted from the beneficiary to the trustee. Since the interval between distributions was still in effect a yearly one, the beneficiary remained on a regular annual schedule and did not suffer any inconvenience." Surrey and Warren, Federal Income Taxation 754 (1955 ed.).

'The general operation of the throwback rule is outlined by proposed Treas. Reg. $\$ 1.665-1$ (1956):" An accumulation distribution is 'thrown back' to each of the five preceding years in inverse order. That is, it will be taxed to the beneficiaries of the trust in the year the distribution is made or required, but in general only to the extent of the distributable net income of those years which was not in fact distributed. However, the resulting tax will not be greater than the aggregate of the taxes that would have been attributable to the amounts thrown back to previous years had they been included in gross income of the beneficiaries in those years. To prevent double taxation, the beneficiaries receive a credit for any taxes previously paid by the trust which are attributable to the excess thrown back."

7 Consult discussion at $160-61$ infra.

${ }^{8}$ Ibid. 
ing trust would be rendered practically valueless as a tax saving device. ${ }^{9}$ Consideration of the proper application of the throwback rule is beyond the scope of this comment for it also raises the issue of whether or not trusts should be separate taxable entities. Finally, given the present law on the trust as a separate tax entity and the application of the throwback rule, one might attack the problem on the intermediary "multiplication of entities" level. While this comment will be limited to the last approach, complete consideration of the problem would require examination of the other possibilities.

Specifically, this comment will examine some of the legal rules producing opportunities for tax minimization through multiple trusts, the past approach of the Commissioner and the courts to the problem, the present safety of using multiple trusts, and the type of legislation that would be most effective in combating this type of tax avoidance.

Trusts can be used to minimize taxation if the income from the corpus is taxed to the trust rather than to the grantor or beneficiaries. ${ }^{10}$ In the 1954 Code the elaborate Clifford sections ${ }^{11}$ provide that the trust's income will not be attributed to the grantor as substantial owner of the corpus ${ }^{12}$ if, in general, the

${ }^{9}$ If all distributions were taxed to the beneficiary (subject to credit for taxes paid previously by the trust), the only major saving accruing from use of the trust entity would be the interest-free use of the funds representing the difference between the taxes paid by the trust on accumulations and the taxes that would have been paid by the beneficiary if the income had been distributed and not accumulated. These funds would be available interest-free from the year the trust paid taxes on the accumulation until the year in which the accumulation was distributed. Another saving might arise where the beneficiary's tax bracket was lower in the later year of distribution than in the earlier year of accumulation. Consult Int. Rev. Code $\S 668(a), 26$ U.S.C.A. $\$ 668$ (a) (1954).

${ }_{10}$ The trust may also be used to save taxes even though the beneficiaries are taxed on trust income. The short-term, non-accumulating trust may be used to spread income among family members who are in lower tax brackets than the grantor.

"1 Int. Rev. Code $\$ \$ 671-78,26$ U.S.C.A. $\$ \$ 671-78$ (1954). On these 1954 Code provisions consult generally, Nance, Taxation of Trust Income to Grantors and Others as Substantial Owners of the Property, 33 Taxes 899 (1955); Casner, The Internal Revenue Code of 1954: Estate Planning, 68 Harv. L. Rev. 222, 228-37 (1954); Craven, Taxation of Estate and Trust Income Under the 1954 Code, 103 U. of Pa. L. Rev. 602-21 (1954); Kamin, Surrey and Warren, The Internal Revenue Code of 1954: Trusts, Estates and Beneficiaries, 54 Col. L. Rev. 1237, 1259-65 (1954). Consult also Holland, Kennedy, Surrey and Warren, A Proposed Revision of the Federal Income Tax Treatment of Trusts and Estates-American Law Institute Draft, 53 Col. L. Rev. 316, 358-67 (1953), which discusses the February, 1954 Draft of the American Law Institute Federal Income Tax Statute. This draft is, with a few exceptions, identical with the 1954 Internal Revenue Code.

${ }^{12}$ Where Int. Rev. Code $\$ \$ 671-78,26$ U.S.C.A. $\$ \$ 671-78$ (1954) indicate that a grantor shall be taxable as substantial owner of the property, these statutory sections are controlling. Conversely, if these sections do not impose tax on the grantor, then the grantor shall not be held taxable on the trust income under any other provisions of the Code "solely on the grounds of his dominion and control over the trust." Ibid., \$671. However, the grantor may still be taxable on the trust income as an assignor of an income right. Sen. Rep. No. 1622, 83rd Cong., 2d Sess. (1954); Harrison v. Schaffner, 312 U.S. 579 (1941); Helvering v. Horst, 311 U.S. 112 (1940); Lucas v. Earl, 281 U.S. 111 (1930); Rev. Rul. 55-2, 1955-1 Cum. Bull. 211 (1955). If the grantor is taxable as substantial owner of the property as a result of his dominion and 
trust may not be revoked, ${ }^{13}$ the income may not be used for the benefit of the grantor, ${ }^{14}$ the grantor retains no reversionary interest which may vest in possession in less than ten years ${ }^{15}$ and the grantor retains no substantial administrative powers ${ }^{16}$ or powers to control beneficial enjoyment. ${ }^{17}$

In situations where the grantor is not taxed, the income beneficiaries, under current law, are taxed ${ }^{18}$ only on that portion of the trust income currently dis-

control over the trust, then he is entitled to the deductions and tax credits attributable to the trust to the extent the Code allows such deducations and credits to individual taxpayers. Int. Rev. Code $\$ 671,26$ U.S.C.A. $\$ 671$ (1954).

13 Int. Rev. Code $\$ 676$ (a), 26 U.S.C.A. $\$ 676$ (a) (1954) provides that the grantor will be treated as owner of any portion of a trust if "the power to revest in the grantor title to such portion is exercisable by the grantor or ['any person (not) having a substantial beneficial interest in the trust which would be adversely affected by the exercise or nonexercise of the power which he possesses respecting the trust.' (Ibid., $\$ 672[a])]$ or both." Such a power of revocation does not, however, render the grantor taxable if it is a power over income that cannot be exercised within ten years of the transfer in trust. Ibid., $\$ 676(\mathrm{~b})$.

${ }^{14}$ Int. Rev. Code $\$ 677,26$ U.S.C.A. $\$ 677$ (1954) treats the grantor as owner of the trust if the income may be distributed to him currently, accumulated for future distribution to him, or applied to payment of premiums on the grantor's life insurance. The grantor is also taxable to the extent that any trust income is actually applied or distributed for the support of anyone whom the grantor is legally obligated to support.

${ }^{15}$ Int. Rev. Code $\$ 673($ a), 26 U.S.C.A. $\$ 673$ (a) (1954) sets forth the general rule rendering the grantor taxable if any interest in corpus or income "will or may be expected to take effect in possession or enjoyment within 10 years" from the transfer in trust. The time period is cut to two years if the income beneficiary is a church, hospital, or educational organization. Ibid., \$673(b). If the reversionary interest takes effect in possession or enjoyment after death, the grantor is not taxable even though the income beneficiary has a life expectancy of less than ten years. Ibid., \$673(c).

${ }^{16}$ Int. Rev. Code $\$ 675,26$ U.S.C.A. $\$ 675$ (1954) provides, in general, that the grantor shall be treated as the substantial owner of the property if he (1) retains a power to deal with the corpus or income for less than an adequate and full consideration, (2) retains a power to borrow corpus or income without adequate interest or security, (3) has actually borrowed corpus or income and has not repaid before the beginning of the taxable year (except where the unrepaid loan provides for both adequate interest and adequate security and was made by a trustee other than the grantor or a person subservient to the grantor) or (4) has retained a power to exercise specified types of voting or investment control over the corpus. Powers held by a non-adverse party to borrow or deal with the corpus also render the grantor taxable.

${ }^{17}$ The grantor is treated as the substantial owner of the property under Int. Rev. Code $\$ 675,26$ U.S.C.A. $\$ 675$ (1954) if he or a non-adverse party retains a power (exercisable without approval of an adverse party) of disposition over income or corpus. A large number of powers are excepted from the general rule, e.g., certain powers to allocate among charitable beneficiaries. Special rules are established for powers exercisable only by "a trustee or trustees, none of whom is the grantor, and no more than half of whom are related or subordinate parties who are subservient to the wishes of the grantor," ibid., $\$ 674$ (c); this provision encourages use of corporate trustees. Still other rules are established for "trustee or trustees, none of whom is the grantor or spouse living with the grantor."

${ }_{18}$ The rule of Irwin v. Gavit, 268 U.S. 161 (1925), that the gift exemption does not apply to income distributions from testamentary trusts, has been incorporated in Int. Rev. Code $\$ 102,26$ U.S.C.A. $\$ 102$ (1954). Sections $641-68$ control income taxation of trusts and beneficiaries. On income taxation of trusts, consult generally: Casner, The Internal Revenue Code of 1954: Estate Planning, 68 Harv. L. Rev. 433, 461-77 (1955); Craven, Taxation of Estate and Trust Income Under the 1954 Code, 103 U. of Pa. L. Rev. 602-21 (1955); Fleming, 
tributed or required to be distributed up to a maximum equal to the distributable net income. ${ }^{19}$ To assure that current income will be taxed to the trust, it must be accumulated and distributed when no longer current. The 1954 Code attempts to discourage such arrangements by a five-year throwback rule ${ }^{20}$ under which distributions of accumulations from the preceding five years ${ }^{21}$ are taxed to the beneficiary, either by including the distribution in the beneficiary's gross income in the year of distribution or by treating the distribution as having been made in the year such income was earned by the trust. ${ }^{22}$ But, the intended effect of the throwback rule may largely be avoided as the rule does not apply ${ }^{23}$ to a distribution of income accumulated for a minor, ${ }^{24}$ to a distribution to meet the "emergency needs" of a beneficiary, ${ }^{25}$ to a final distribution made

One Year of Trust Income Taxation Under the 1954 Code, 33 Taxes 892 (1955); Fleming, Income Taxation of Trusts and Estates Under the 1954 Code, 32 Taxes 931 (1954); Kamin, Surrey and Warren, The Internal Revenue Code of 1954: Trusts, Estates and Beneficiaries, 54 Col. L. Rev. 1237-59 (1954). Consult also Holland, Kennedy, Surrey and Warren, A Proposed Revision of the Federal Income Tax Treatment of Trusts and Estates-American Law Institute Draft, 53 Col. L. Rev. 316-54 (1953) which discusses the February, 1954 Draft of American Law Institute Federal Income Tax Project.

${ }^{19}$ Distributable net income, a concept introduced in the 1954 Code, is designed to determine which distributions to a beneficiary are includible in the beneficiary's return as income from property and which are excluded as corpus distributions. Int. Rev. Code $\$ 643(a), 26$ U.S.C.A. $\$ 643$ (a) (1954) defines distributable net income as basically the taxable income of the trust before the trustee's deduction for distributions and the deduction for personal exemption; a number of other adjustments to taxable income must be made in certain situations, e.g., taxexempt interest. Income currently distributed or required to be currently distributed is includible in gross income of the beneficiary to the extent of the distributable gross income. Ibid., $\$ \$ 652(a), 622(a)$. State law determines whether or not income is required to be distributed currently. See Estate of Cohen v. Comm'r, 8 T.C. 784 (1947); Case v. Comm'r, 8 T.C. 343 (1947), both applying local law in accordance with similar provisions of the 1939 Code.

${ }^{20}$ Int. Rev. Code $\$ \$ 665-68,26$ U.S.C.A. $\$ \$ 665-68$ (1954). For a discussion of the throwback rule, consult generally: Surrey and Warren, Federal Income Taxation 756-61 (1955 ed.); Casner, The Internal Revenue Code of 1954: Estate Planning, 68 Harv. L. Rev. 433, 465-72 (1955); Foosaner, Five-Year Throwback Rule, 95 Trusts \& Estates 688 (1956).

${ }^{21}$ Consult Int. Rev. Code $\$ 665(b), 26$ U.S.C.A. $\$ 665$ (b) (1954) for the definition of "accumulation distribution."

${ }^{2}$ Consult note 6 supra.

${ }^{23}$ Technically, most of the exceptions operate by excluding certain types of distributions from the definition of "accumulation distributions." Int. Rev. Code $\$ 665(b), 26$ U.S.C.A. $\S 665(\mathrm{~b})$ (1954).

24 Int. Rev. Code $\S 665(b)(1), 26$ U.S.C.A. $\S 665(b)(1)$ (1954) excludes distributions of "income accumulated before the birth of such beneficiary or before such beneficiary attains the age of 21."

${ }^{25}$ Int. Rev. Code $\$ 665(\mathrm{~b})(2), 26$ U.S.C.A. $\$ 665(\mathrm{~b})(2)$ (1954). "Emergency needs" are not defined in the Code, but Sen. Rep. No. 1,622, 83rd Cong., 2d Sess. 357 (1954) states, "A distribution based upon an unforeseen or unforeseeable combination of circumstances requiring immediate help to the beneficiary would qualify. However, the beneficiary must be in actual need of the distribution. The fact that a beneficiary has other sufficient resources would tend to negate the conclusion that a distribution was to meet his emergency needs." This exception, therefore, offers little opportunity for tax planning. 
more than nine years after the last transfer to the trust, ${ }^{26}$ to accumulations not in excess of $\$ 2,000,27$ or to certain gifts of specific sums or properties paid in not more than three installments. ${ }^{28}$ The taxpayer can take advantage of these exceptions most adequately through use of multiple trusts. For example, the threeinstallment, specific-sum exception ${ }^{29}$ can be utilized by establishing three trusts, each distributing in turn every three years beginning in the first year and terminating tax-free three years after its third installment, thereby assuring the beneficiary a tax-free distribution for each of the twelve consecutive years. Similarly, if a number of trusts each have income of less than $\$ 2,000$ a year, accumulations in one year for distribution in the following year will escape the throwback rule. ${ }^{30}$

Of the few cases involving multiple trusts, none have dealt with the permissibility of their use to minimize taxation. Rather, the cases have involved only a construction of the trust instrument to determine how many trusts actually were created. ${ }^{31}$ The expressed intention of the grantor as indicated in the trust

25 Int. Rev. Code $\$ 665(b)$ (4), 26 U.S.C.A. $\$ 665(b)(4)$ (1954).

${ }^{27}$ Int. Rev. Code $\$ 665(\mathrm{~b}), 26$ U.S.C.A. $\$ 665(\mathrm{~b})$ (1954). The accumulation distribution is carried back to the first preceding year only if it exceeds $\$ 2,000$, but in determining carryback to the second through fifth preceding years the size of the remaining accumulation is immaterial.

${ }^{28}$ Int. Rev. Code $\$ 663(a)(1), 26$ U.S.C.A. $\$ 663(a)(1)$ (1954). This exception operates by excluding such amounts from the "amounts properly paid or credited or required to be paid or credited" under $\$ 661$ (a)(2) and thus reducing the "accumulation distribution" under $\$ 665(\mathrm{~b})$.

${ }^{29}$ Int. Rev. Code \$663(a)(1), 26 U.S.C.A. \$663(a)(1) (1954).

${ }^{30}$ For examples of other possible uses of multiple trusts consult Surrey and Warren, Federal Income Taxation 763-64 (1955 ed.).

31 The problem has arisen most often from the use of a single instrument to create several trusts. The ambiguity has been resolved by an examination of whether the instrument refers to the singular "trust," see Hale v. Dominion National Bank, 186 F.2d 374 (C.A. 6th, 1951); Belcher Trust v. Comm'r, 6 T.C.M. 967 (1947); Reid Trust v. Comm'r, 6 T.C. 438 (1946); Hiecke Trust v. Comm'r, 6 T.C. 30 (1946); Huntington National Bank v. Comm'r, 90 F.2d 876 (C.A. 6th, 1937), or the plural "trusts," see Lane v. United States, 83 F.Supp. 260 (E.D. Mo., 1948); Fiduciary Trust Co. v. United States, 36 F.Supp. 653 (S.D.N.Y., 1940). But see Kohtz Trust v. Comm'r, 5T.C. 554 (1945); Marx v. Comm'r, 39 B.T.A. 537 (1939). In both the latter cases the instrument used the singular "trust" but the court, holding that multiple trusts were created, relied heavily on the use of the plural "shares."

It is well settled that multiple trusts can be created although the corpus of each consists of an undivided interest in a common res. U.S. Trust Co. v. Comm'r, 296 U.S. 481 (1936); Helvering v. McIlvaine, 296 U.S. 488 (1936); see Belcher Trust v. Comm'r, 6 T.C.M. 967 (1947); Kohtz Trust v. Comm'r, 5 T.C. 554 (1945); Fidelity Union Trust Co. v. Kelly, 102 F.2d 986 (C.A.3d, 1939); Fidelity Union Trust Co. v. Kelly, 102 F.2d 333 (C.A.3d, 1939); St. Louis Union Trust Co. v. Comm'r, 40 B.T.A. 165 (1939); Marx v. Comm'r, 39 B.T.A. 537 (1939); Davis v. Comm'r, 37 B.T.A. 587 (1938); Tiernan v. Comm'r, 37 B.T.A. 1048 (1938); Union Trust Co. v. Comm'r, 84 F.2d 386 (C.A. 3d, 1936). Other factors considered significant by the court include: if the instrument were construed to create one trust, the rule against perpetuities would be violated. Grace Trust v. Comm'r, 13 T.C. 632 (1949); one clause of the trust instrument, which allowed the trustee to distribute a maximum of $\$ 5,000$ out of the invested corpus but provided that in no event could the original corpus be distributed, led to the conclusion that the grantor intended a single trust rather than a parent trust with subsidiary trusts receiv- 
instrument was deemed controlling ${ }^{32}$ until 1954 when Judge Learned Hand in McHarg v. Comm' ${ }^{33}$ insisted that multiple trusts would be recognized only where the instrument, under property law, actually created separate and independent trusts. ${ }^{34}$ The problem in $M c H$ arg and previous construction cases probably could have been avoided through use of a separate instrument for each trust.

Whether or not a taxpayer can successfully use multiple trusts will depend in part on the ability of the Commissioner to strike down the separate entities in the courts. In comparable multiple-entity situations ${ }^{35}$ such as use of multiple corporations to secure additional $\$ 25,000$ surtax exemptions ${ }^{36}$ and $\$ 25,000$ minimum excess profits tax credits, ${ }^{37}$ there has never been a case decided on

ing the parent's income, Hale v. Dominion National Bank, 186 F.2d 374 (C.A. 6th, 1951); the treatment by the trustee of the res as the corpus of a single trust was significant because "[i]t is a fair assumption in the usual case that the trustee has been consulted by the trustor in respect to acceptance of the trust and has some knowledge of his intention." Huntington $\mathrm{Na}$ tional Bank v. Comm'r, 90 F.2d 876, 878 (C.A. 6th, 1937); discretionary authority given the trustee to keep the corpus in a consolidated fund indicates the existence of multiple trusts for, "If a single trust was intended, the discretionary power here given the trustee would be unnecessary." Fiduciary Trust Co. v. United States, 36 F.Supp. 653 (S.D.N.Y., 1940).

${ }^{32}$ See, e.g., Hale v. Dominion National Bank, 186 F.2d 374 (C.A. 6th, 1951); Hiecke Trust v. Comm'r, 6T.C. 30 (1946). Where the intention disclosed in the preamble conflicts with the intention disclosed in the granting clauses, the latter controls. Fidelity Union Trust Co. v. Kelly, 102 F.2d 986 (C.A. 3d, 1939); Fidelity Union Trust Co. v. Kelly, 102 F.2d 333 (C.A. $3 d, 1939)$. The intention disclosed by the trust instrument is more important than the administrative treatment of the res by the trustee. See Hiecke Trust v. Comm'r, 6 T.C. 30 (1946); MaciManus v. Comm'r, 131 F.2d 670 (C.A. 6th, 1942); but see Huntington National Bank v. Comm'r, 90 F.2d 876 (C.A. 6th, 1937).

33210 F.2d 792 (C.A. 2d, 1954).

${ }^{34}$ Hand distinguished the settlor's intent to create "those limitations that the settlor in fact does create" from the intent "that those limitations shall be treated as one trust, or as several." 210 F.2d 792, 794 (C.A. 2d, 1954). The later intent, he argued, was immaterial, for use as indicia of the number of trusts the "belief or desire of the settlor about what he has created" would be anomalous as the settlor "may create what he likes, but he may not say how it shall be taxed." Ibid., at 795.

${ }^{35}$ Consult Cohen, Exemptions and Credits of Multiple Corporations: Sections 15(c) and 129 [1953] So. Calif. Tax Inst. 1-3. On multiple corporations, consult generally: Rice, Internal Revenue Code, Section 269: Does the Left Hand Know What the Right Is Doing, $103 \mathrm{U}$. of Pa. L. Rev. 579 (1955); Cohen, Exemptions and Credits of Multiple Corporations: Sections 15(c) and 129, [1953] So. Calif. Tax Inst. 1; Landman, Multiplying Business Corporations and Acquiring Tax Losses, 8 Tax I. Rev. 81 (1952); Mintz, Attempts to Multiply Taxable Entities: A New Warning, 4 Am. U. Tax Inst. Lectures 25 (1952).

${ }^{35}$ At present the $22 \%$ surtax is applicable only to taxable income in excess of $\$ 25,000$. Int. Rev. Code $\$ 11(\mathrm{c}), 26$ U.S.C.A. \$11(c) (1954).

${ }^{37}$ Under the excess profits tax each corporation was given a $\$ 25,000$ minimum excess profits tax credit. Int. Rev. Code $\$ 430,26$ U.S.C.A. $\$ 430$ (1939), amended by Revenue Act of 1950 , 64 Stat. 1137 (1950). An additional advantage from multiple corporations accrued through the limitation on the total of income tax plus excess profits tax. Int. Rev. Code $\$ 430$ (a)(2), 26 U.S.C.A. $\$ 430(a)(2)$ (1939), amended by Excess Profits Tax Act of 1950, 64 Stat. 1137 (1950). 
general case-law principles involving the taxpayer's power to minimize taxation by creation of multiple entities. The Commissioner, faced with this dearth of directly applicable authority and unwilling to rely on general case-law precedents, secured legislation from Congress before attacking the multiple entities. ${ }^{38}$ None of this legislation is in terms, or as construed, applicable to multiple trusts.

In cases not involving multiple entities, however, the courts repeatedly have held transactions taxable which appeared to be non-taxable. The doctrinal basis of such decisions has usually been obscured by the court's use of ambiguous epithets such as "sham"39 and "unreal" 40 to condemn the transaction. Such "decision by invective" 41 offers little aid in analysis of the cases. These taxavoidance cases are of two kinds: first, cases where the taxpayer has not done in fact what he has purported to do and therefore is taxed on what he has actually done; and second, cases where, although the taxpayer has actually done what he has purported to do, he is taxed because he has only a tax avoidance, and not a business, purpose.

The case which most illuminates the first category is Chisholm v. Commission$e r .{ }^{42}$ The taxpayer and three others wished to sell appreciated securities but delay recognition of the gain. The securities, being all the shares of a corporation, were transferred to a partnership which consummated the sale and used the proceeds for trading in securities. ${ }^{43}$ The Commissioner argued and the Board of Tax Appeals agreed ${ }^{44}$ that the transaction was not bona fide and that the taxpayer was taxable on the gain. ${ }^{45}$ The circuit court reversed, holding that

${ }^{38}$ Consult discussion at 168-69 infra.

39 E.g. Moline Properties v. Comm'r, 319 U.S. 436, 439 (1943).

${ }^{10}$ E.g., Burnet v. Gugenheim, 288 U.S. 280, 284 (1933). It has been stated that "fictions" should be disregarded, Bradley v. Comm'r, 1 B.T.A. 111, 117 (1924); that courts should "not be blinded by form or lose sight of the substance," Chisholm v. Comm'r, 29 B.T.A. 1334, 1340 (1934), rev'd 79 F.2d 14 (C.A. 2d, 1935); that "[a] given result at the end of a straight path is not made a different result because reached by following a devious path," Minnesota Tea Co. v. Helvering, 302 U.S. 609,613 (1938); that the courts must not "exalt artifice above reality," Gregory v. Helvering, 293 U.S. 465,470 (1935); that "transactions to be effective ... must have reality," Comm'r v. Greenspun, 156 F.2d 917, 920 (C.A. 5th, 1946); that "outer form is not enough for tax purposes," Barrett v. Comm'r, 185 F.2d 150, 151 (C.A. 1st, 1950); and that "form" must not "obscure the reality," Harrison v. Schaffner, 312 U.S. 579, 583 (1941). One per curiam opinion listed the following epithets-sham, disguise, masquerade, fiction, subterfuge, make-believe, mere pretense, mask, screen, veil, artifice and ruse. Kocin v. United States, 187 F.2d 707, 708 (C.A. 2d, 1951.)

11 Rice, Judicial Techniques in Combating Tax Avoidance, 51 Mich. L. Rev. 1021, 1026 (1953).

1279 F.2d 14 (C.A. 2d, 1935).

${ }^{43}$ The taxpayer was attempting to fit the transaction within the rule of Helvering v. Walbridge, 70 F.2d 683 (1934).

11 George H. Chisholm, 29 B.T.A. 1334 (1934).

${ }^{15}$ The Commissioner in Chisholm v. Comm'r, 79 F.2d 14 (1935), was relying on Gregory v. Helvering, 293 U.S. 465 (1935). 
a partnership actually had been formed and that it was not "in effect the former separate businesses of the brothers conducted under a disguise." ${ }^{\text {"66 }}$ Thus, in the first category of cases, ${ }^{47}$ " $[t]$ he question always is whether the transaction under scrutiny is in fact what it appears to be in form." 48 That is, the courts are deciding whether or not the taxpayer has done what he has purported to do. Minimization of taxes through multiple trusts cannot be successfully attacked by the Commissioner through this factual approach, for it cannot be maintained that multiple trusts have not in fact been created if the trust instruments are properly drafted and the formalities of property law observed. ${ }^{49}$

In the second category are cases where, although the taxpayer has done what he has purported to do, he has so acted only for a tax-avoidance, and not a business, purpose. In the leading case of Gregory v. Helvering,,$^{50}$ the taxpayer was sole shareholder of a holding company which held certain low-basis securities which the taxpayer wished to sell if the cash could flow to her without realization of ordinary income through a dividend distribution. The shares of a subsidiary, created to hold the securities for three days, were spun-off to the taxpayer, and three days later she liquidated the subsidiary and sold the low-basis securities. The taxpayer contended that the spin-off constituted a tax-free reorganization, that the liquidation of the subsidiary produced a capital gain, and that the subsequent sale of the securities produced no gain. ${ }^{51}$ However, the

${ }^{48}$ Chisholm v. Comm'r, 79 F.2d 14, 15 (1935).

17 See Chamberlin v. Comm'r, 207 F.2d 462 (C.A. 6th, 1953); United States v. Cummins Distilleries Corp., 166 F.2d 17 (C.A. 6th, 1948); Howell Turpentine Co. v. Comm'r, 162 F.2d 319 (C.A. 5th, 1947); Meurer Steel Barrel Co. v. Comm'r, 144 F.2d 282 (C.A. 3d, 1944); Hobby v. Comm'r, 2 T.C. 980 (1943); Comm'r v. Falcon Co., 127 F.2d 277 (C.A. 5th, 1942); Morsman v. Comm'r, 90 F.2d 18 (C.A. 8th, 1937).

18 Chisholm v. Comm'r, 79 F.2d 14, 15 (1935). Judge Hand continued: "[A] marriage may be a joke; a contract may be intended only to deceive others; an agreement may have a collateral defeasance. In such cases, the transaction as a whole is different from its appearance." Ibid. One test used was whether or not the transaction was legally binding. Randolph Paul restated this test, "Are the parties to a transaction bound to unite to undo the transaction, or is the transaction so firm as to require a new agreement to undo it? It is always inherent in any transaction that the parties may make a new deal, obliterating the old transaction. The question is whether a new deal is vital to undoing." Paul, Studies in Federal Taxation 129 (1937). This latter test cannot be accepted as a sole test of taxability, for many transactions purporting to be tax-free have been held taxable although they were legally binding. See, e.g., National Carbide Corp. v. Comm'r, 336 U.S. 422 (1949); Comm'r v. Sunnen, 333 U.S. 591 (1948); Bazley v. Comm'r, 331 U.S. 737 (1947).

${ }^{49}$ See McHarg v. Comm'r, 210 F.2d 792 (C.A. 2d, 1954).

${ }^{50} 293$ U.S. 465 (1935).

s1 The taxpayer argued that upon the spin-off part of her basis for stock in the parent should be allocated to the newly-received stock in the subsidiary. Upon liquidation of the subsidiary, the taxpayer would then recognize a gain, taxable at the capital gains rate, equal to the excess of the fair market value of the securities, the subsidiary's only assets, over the basis that had been allocated to the subsidiary. As the liquidation was taxable, the taxpayer obtained a basis for the securities equal to their fair market value and therefore the subsequent sale resulted in no gain. 
Supreme Court held that the spin-off constituted a dividend of the subsidiary's shares taxable at ordinary income rates because, although the technical provisions of the Code reorganization section had been scrupulously followed, the reorganization had no "business or corporate purpose" $"$ and therefore did not qualify as a tax-free reorganization under the statute..$^{53}$

The Gregory principle-that the tax consequences of a transaction which serves solely a tax-avoidance purpose are to be determined without regard to the formalities of the transaction-has come to be known as the business purpose doctrine. ${ }^{54}$ Although at first limited to reorganizations, ${ }^{55}$ it has been extended to disallow otherwise available deduction ${ }^{56}$ and, in the form of a business activity test, to disregard corporate entities. ${ }^{57}$ The Gregory principle has never, however, been applied as a "trust purpose" 38 doctrine.

52 Gregory v. Helvering, 293 U.S. 465, 469 (1935).

${ }^{33}$ Technically, Gregory v. Helvering, 293 U.S. 465 (1935), was a statutory construction case insofar as it decided whether the transaction was a "transfer of assets" within the language of the statute. Ibid., at 469. See Comm'r v. National Carbide Corp., 167 F.2d 304, 306 (C.A. 2d, 1948). A statutory construction analysis could be used to determine whether or not the separate entities involved in multiple trusts constitute "trusts" within the meaning of Int. Rev. Code $\$ \$ 641-68,26$ U.S.C.A. $\$ \$ 641-68$ (1954).

s1 On the business-purpose doctrine, consult generally: Rice, Judicial Techniques in Combating Tax Avoidance, 51 Mich. L. Rev. 1021, 1041-46 (1953); Michaelson, "Business Purpose" and Tax Free Reorganization, 61 Yale L. J. 14 (1952); Spear, "Corporate Business Purpose" in Reorganization, 3 Tax. L. Rev. 225 (1947); Lourie, The Business Purpose Doctrine, 25 Taxes 800 (1947). The business purpose doctrine appears unalterably contrary to the now-ancient exhortation that motive in taxation is immaterial. See United States v. Isham, 17 Wall. (U.S.) 496 (1873). Consult Paul, Studies in Federal Taxation 104-7 (1937), and authorities cited therein. Only by investigating the taxpayer's "purpose" was the Court in Gregory v. Helvering, 293 U.S. 465 (1935), able to determine whether a tax-free reorganization existed. Curiously, the Gregory case paid lip service to the motive-is-immaterial shibboleth.

${ }^{5 s}$ See Minnesota Tea Co. v. Helvering, 302 U.S. 609 (1938).

${ }^{56}$ Kocin v. United States, 187 F.2d 707 (C.A. 2d, 1951).

57 Under the business activity doctrine, the Commissioner may impose taxation as if the corporation did not exist if the corporation engages in no business activity. See National Carbide Corporation v. Comm'r, 336 U.S. 422 (1949); Hay v. Comm'r, 145 F.2d 1001 (C.A. 4th, 1944); National Investors Corp. v. Hoey, 144 F.2d 466 (C.A. 2d, 1944); Higgins v. Smith, 308 U.S. 473 (1940). The taxpayer has much more difficulty in persuading courts to disregard a corporate entity in order to lower taxes. Moline Properties, Inc. v. Comm'r, 319 U.S. 436 (1943); Bumet v. Commonwealth Improvement Co., 287 U.S. 415 (1932). But cf. Paymer v. Comm'r, 150 F.2d 334 (C.A. 2d, 1945). On disregarding the corporate entity, consult generally: Armstrong, Shall We Have a Clifford Doctrine for Corporations?, 24 Taxes 830 (1946); Cleary, The Corporate Entity in Tax Cases, 1 Tax L. Rev. 3 (1945); Case, Disregard of Corporate Entity in Federal Taxation, 30 Va. L. Rev, 398 (1944).

The business purpose doctrine has also been extended to: disregard of partnerships, see Kocin v. United States, 187 F.2d 707 (C.A. 2d, 1951); family partnerships, Goodman v. Comm'r, 200 F.2d 681 (C.A. 2d, 1953); corporate distributions, Bazley v. Comm'r, 331 U.S. 737 (1947); inter-family gifts, Gouldman v. Comm'r, 165 F.2d 686 (C.A. 4th, 1948); corporate liquidations, Comm'r v. Webster's Estate, 131 F.2d 426 (C.A. 5th, 1942); sale and leaseback arrangements, Schaffer Terminals, Inc. v. Comm'r, 194 F.2d 539 (C.A. 9th, 1952); and gift and leasebacks, dissent in White v. Fitzpatrick, 193 F.2d 398, 402 (C.A. 2d, 1951).

s8 Surrey and Warren, Federal Income Taxation 764 (1955 ed.). 
Extension of the Gregory principle to the trust area involves difficulties not present in business situations, where it admittedly works imperfectly. Use of the trust, a very flexible property planning device, is encouraged by its advantageous tax features. With tax considerations thus permeating the trust field, determining whether or not there is a "trust purpose" for splitting a single trust into several entities presents a more difficult issue than whether or not there is a "business purpose" in a given business transaction. Nevertheless, a trust purpose doctrine would embody an element of usefulness if the test were whether or not there was a non-tax reason for the use of several entities rather than one. Perhaps the greatest difficulty is that the careful tax planner would be able to create the appearance of a trust purpose for each of a limited number of trusts. A trust for each child of the grantor, ${ }^{59} \mathrm{a}$ trust for each business or parcel of real property, ${ }^{60}$ or separate trusts to insulate conservative security investments from liabilities incurred by highly risky businesses to be held in trust would appear to be reasonably safe from any foreseeable extension of a trust purpose doctrine.

In conclusion, the Commissioner appears to have no precedents or other means to attack multiple trusts, provided the taxpayer plans each trust to meet possible development of a trust purpose doctrine ${ }^{61}$ and observes all formalities necessary to create separate and independent trusts. The Chisholm line of cases appears doctrinally inapplicable, the Gregory business-purpose precedents seem unlikely to reach a well-planned trust program, and the comparable multiple entity cases in the business area have all relied on special legislation.

Legislation aimed at the multiple trust problem could be of two types: explicative or directional. The explicative statute attempts to provide set rules for every factual variation while the directional statute merely provides a statutory standard to be applied by the courts. Typical of the explicative statute are the Clifford trust provisions, ${ }^{62}$ the incorporation and reorganization provisions, ${ }^{63}$ and the distribution in redemption of stock provisions. ${ }^{64}$ In the multiple trust area such a statute would establish specific, objective rules for determining

${ }^{59}$ The separate trusts for each child might be justified, for example, by a necessary difference in investment policies. For a daughter, conservation of principal and stability of income might properly be the prime considerations. For a talented son, stability of income might properly be sacrificed in order to achieve appreciation of capital. Further, a trust for a sickly child might well allow the trustee to invade corpus in emergencies while a trust for a healthy child might have no such provisions. The possible variations are unlimited, and the Commissioner may well be unable to determine whether or not the differences are justified by factors which likely are known only within the family.

${ }^{60}$ The taxpayer in demonstrating a trust purpose could point to the custom of office or apartment building owners of holding each building in a separate corporation.

${ }^{61}$ A large number of trusts are unnecessary. In the example in note 3 supra, use of one hundred trusts would save only $34 \%$ more in taxes than use of five trusts.

${ }^{62}$ Int. Rev. Code $\$ \$ 671-78,26$ U.S.C.A. $\$ \$ 671-78$ (1954).

63 Int. Rev. Code $\$ \S 351-68,26$ U.S.C.A. $\$ \S 351-68$ (1954).

${ }^{64}$ Int. Rev. Code $\$ \S 302,317$ (b), 318(a), 26 U.S.C.A. $\$ \S 302,317$ (b), 318(a) (1954). 
whether multiple trusts would be taxed separately or on a consolidated basis; $;^{65}$ the most feasible guiding principle appears to be that income should be consolidated where two or more essentially similar trusts are created by the same grantor for the same beneficiaries. ${ }^{66}$

An explicative statute would have three major disadvantages. First, the draftsman would have no experience with the patterns of utilization of multiple trusts for tax avoidance purposes or with the difficulties of attacking multiple trusts. The necessity of such experience explains in part why the Clifford trust statutory provisions ${ }^{67}$ were not enacted until fourteen years after Helvering v. Clifford. ${ }^{68}$ Second, use of the trust, one of the most flexible of all property devices, might be seriously restricted by arbitrary provisions aimed at preventing the use of trusts for tax avoidance purposes. Third, closely defined limits on taxability invite the tax-conscious grantor to focus on achieving the maximum tax advantages, often at the detriment of sound property planning; conversely, as the statute would indicate exactly how far the taxpayer might proceed in establishing multiple trusts, ${ }^{69}$ its application would most often frustrate the poorly advised grantor's plans, assuming the statute applied only to subsequently created trusts.

Legislation aimed at the multiple trust device probably should be of the directional type-that is, it should establish a statutory standard. ${ }^{70} \mathrm{~A}$ directional statute would have two primary advantages. First, family property planning would not be inhibited where the taxpayer could demonstrate that his use of trusts was motivated by sound non-tax considerations. Second, the tax-

${ }^{65}$ Consult discussion at 169 infra.

${ }^{66}$ Attribution provisions would be necessary to prevent reciprocal trust arrangements, but such a provision would be extremely difficult to draft for trusts are traditionally used for intra-family purposes and therefore the assumptions underlying sections such as Int. Rev. Code $\$ 318,26$ U.S.C.A. $\$ 318$ (1954), are inapplicable.

${ }^{67}$ Int. Rev. Code $\$ \$ 671-78,26$ U.S.C.A. $\$ \$ 671-78$ (1954).

es 309 U.S. 331 (1940). For an analogy, consult Paul, Studies in Federal Taxation 3-165 (1940), for a description of the slow and painful growth of the reorganization provisions, a process not yet complete.

${ }^{69}$ For example, under Int. Rev. Code $\$ 302(b)(2), 26$ U.S.C.A. $\$ 302(b)(2)(1954)$, a taxpayer knows exactly how many shares must be redeemed in order to qualify as a "substantially disproportionate redemption of stock" and thus receive capital gain treatment. On the other hand, this same factor of certainty of tax results in business and property planning is the strength of the explicative statute.

70 Examples of such a standard are "clearly reflect income," Int. Rev. Code $\$ 446(\mathrm{~b})$, 26 U.S.C.A. \$446(b) (1954), and "essentially equivalent to a . . dividend," Int. Rev. Code $\$ 115(\mathrm{~g}), 26$ U.S.C.A. $\$ 115(\mathrm{~g})(1939)$. Under the 1954 Code the distribution in redemption of stock provision was changed to an explicative statute, but because the specific provisions might not cover all possible situations, the "essentially equivalent to a dividend" language was retained to indicate an area beyond that delineated by specific provisions where ordinary income treatment could be accorded the distribution. Int. Rev. Code $\$ 302(b)(1), 26$ U.S.C.A. $\$ 302(b)(1)(1954)$. 
conscious grantor would be restrained from using multiple trusts solely to minimize taxation for he would be unsure how far the courts would go in applying the statute.

Three directional sections already have been enacted to deal with various facets of the analogous multiple corporation problem. One, which disallows de-ductions, credits, or allowances in certain corporate acquisitions where "the principal purpose for which such acquisition was made is evasion or avoidance of Federal income tax ...,"71 has been singularly unsuccessful in dealing with split-ups and other multiplications of corporate entities because of its use of the definite article. "[T]he principal purpose" (italics added) was interpreted to mean that avoidance of taxation must be more important than any other purpose, and the taxpayers were able to demonstrate an important non-tax purpose for each entity. ${ }^{72}$

Consequently, when a second section ${ }^{73}$ was enacted to disallow the $\$ 25,000$ surtax exemption and the $\$ 25,000$ minimum excess profits tax credit to multiple corporations,${ }^{74}$ the indefinite article " $\mathrm{a}$ " was used in order to avoid the limitations of the prior statute. This section, applicable where avoidance of taxation is " $a$ major purpose"75 (italics added), has never been judicially tested.

A third section, ${ }^{76}$ giving the Commissioner power to allocate income and deductions among "two or more organizations, trades or businesses if such action is necessary in order to prevent evasion of taxes or clearly to reflect the income ..."77 has been held applicable to multiple corporations only if income

${ }^{71}$ Int. Rev. Code $\$ 269$ (a), 26 U.S.C.A. $\$ 269$ (a) (1939). This language was first passed in simpler form in the Revenue Act of 1943,58 Stat. 47 (1943). The section was primarily designed to combat "the recently developed practice of corporations with large excess profits (or the interests controlling such corporations) acquiring corporations with current, past, or prospective losses or deductions, deficits, or current or unused excess profits credits, for the purpose of reducing income and excess profits taxes." Sen. Rep. No. 627, 78th Cong. 1st Sess. 58 (1943).

72 For example, in Alcorn Wholesale Co. v. Comm'r, 16 T.C. 75 (1951), the court found the following business reasons for the creation of multiple corporations for conducting a grocery wholesale business: increased borrowing ability under state banking statutes, limitation of liability for tort judgments, ability to incorporate in each state to avoid prejudice against absentee ownership, and ability to obtain franchises for competing lines of merchandise. See also Chelsea Products, Inc. v. Comm'r, 16 T.C. 840 (1951), aff'd 197 F.2d 620 (C.A. 3d, 1952); Berland's Inc. of South Bend v. Comm'r, 16 T.C. 182 (1951); Dilworth Co. v. Henslee, 98 F.Supp. 957 (M.D. Tenn., 1951). Consult Treas. Reg. 111, \$29.129-3 (1945). But see Alpha Tank and Sheet Metal Mfg. Co. v. United States, 116 F.Supp. 721 (Ct. Cl., 1953) (semble).

${ }^{73}$ Int. Rev. Code $\$ 1551,26$ U.S.C.A. $\$ 1551$ (1954). This section was introduced in slightly different form by the Revenue Act of 1951, 65 Stat. 468 (1951).

${ }^{74}$ Consult notes 36 and 37 supra.

${ }^{75}$ Int. Rev. Code $\$ 1551,26$ U.S.C.A. \$1551 (1954).

${ }^{76}$ Int. Rev. Code $\$ 482,26$ U.S.C.A. $\$ 482$ (1954). This provision was introduced in substantially the present form in the 1939 Code. Int. Rev. Code $\$ 45,26$ U.S.C.A. $\$ 45$ (1939).

${ }^{77}$ Int. Rev. Code $\$ 482,26$ U.S.C.A. $\$ 482$ (1954). 
is arbitrarily shifted from one corporation to another. ${ }^{78} \mathrm{It}$ has also been applied to allow reallocation where business entities have been unnaturally divided. ${ }^{79}$ As trusts holding investment property can, by property accounting procedures, avoid shifting of income, ${ }^{80}$ and as the unnatural division of business entities has no counterpart in the trust field, ${ }^{81}$ such a statute would appear inadequate to solve the multiple trust problem.

Of the statutes applied in the analogous multiple corporation area, the "a principal purpose" directional statute seems preferable. As an expression of congressional intent, it would encourage extension of the Gregory business purpose doctrine to the trust area. Use of the indefinite article would avoid the difficulty of requiring the Commissioner to prove that tax avoidance was more important than all other motives.

Fully as important as the standard to be established is the sanction to be imposed. Although theoretically many modes of enforcement are possible, it appears most feasible to give the Commissioner power to tax the separate trusts together as one trust by consolidation of tax returns or power to tax the trusts' income to the grantor. As it has been assumed that the general status of the single trust as a taxpaying entity will remain unchanged, it is presumptively legitimate for the grantor to use one trust, and taxing all the trusts as one would eliminate all tax avoidance stemming from multiplication of trust entities. A less direct approach ${ }^{82}$ would be taxation of the trusts' income to the

78 See Alpha Tank and Sheet Metal Mfg. Co. v. United States, 116 F.Supp. 721 (Ct. Cl., 1953); Comm'r v. Chelsea Products, Inc., 197 F.2d 620 (C.A. 3d, 1952); Grenada Industries, Inc. v. Comm'r, 17 T.C. 231 (1951), aff'd 202 F.2d 873 (C.A. 5th 1953). Under this section the Commissioner has attributed the income of a number of corporations to a single entity even though Treas. Reg. 111, \$29.45-1(b) (1945) disclaimed any intention of requiring consolidation of tax returns. See Advance Machinery Exchange, Inc. v. Comm'r, 196 F.2d, 1006 (C.A. 2d, 1952). Consult Cooper, Section 45, 4 Tax L. Rev. 131 (1949). Note that Int. Rev. Code $\$ 482,26$ U.S.C.A. $\$ 482$ (1954), applies to "organizations, trades, or businesses." Arguably multiple trusts could be included in "organizations."

The Commissioner has also attacked multiple corporations by using the basic gross income provision, Int. Rev. Code \$22(a), 26 U.S.C.A. \$22(a) (1939), in conjunction with other provisions of the Code. See Advance Machinery Exchange, Inc. v. Comm'r, supra. The same approach might be used against multiple trusts.

79 Cf., e.g., Miles-Conley Co. v. Comm'r, 10 T.C. 754 (1948), where the Commissioner argued that the taxpayer had unnaturally divided his fruit and vegetable commission business between a corporation and a sole proprietorship; the decision, however, recognized the unnatural division doctrine.

${ }^{80}$ Unless the rule of United States Trust Co. v. Comm'r, 296 U.S. 481 (1936), permitting multiple trusts to hold undivided interests in a single corpus, is changed by statute, the collection of income by one trust for distribution to other trusts holding undivided interests in the income-producing property should not be sufficient grounds for the Commissioner to invoke Int. Rev. Code $\$ 482,26$ U.S.C.A. $\$ 482$ (1954). Consult note 31 supra.

${ }^{81}$ It appears impossible to argue that the grantor has unnaturally divided trust property, as factors of safety, investment policy, etc. may properly induce unusual combinations of investments within one trust.

The Code does not always attack problems directly. For example, the collapsible corporation provision, Int. Rev. Code $\$ 341,26$ U.S.C.A. $\$ 341$ (1954), adopts an in terrorem approach. 
grantor; this sanction would have a powerful in terrorem effect, but, insofar as use of a lesser number of trusts would be considered proper, such a drastic penalty would appear illogical.

This comment has suggested a statute giving the Commissioner power to consolidate the returns of multiple trusts where tax minimization has been "a principal purpose" for using a number of trusts rather than a single trust. However, only one of the possible general approaches to the multiple trust problem has been examined. The discussion has indicated that it is apparently impossible to draft an adequate explicative statute and rather difficult to incorporate an "avoidance of taxation" or "trust purpose" standard into the trust area. Experience may demonstrate that there can be no adequate solution without re-examination of a more fundamental concept-recognition of the trust as a separate taxpaying entity. Perhaps the final solution lies in restricting the use of the accumulating trust, possibly by broadening the throwback rule.

\section{COLLISION CLAUSES IN AUTO INSURANCE POLICIES-RECOVERY FOR DAMAGE BY FALLING OBJECTS OR ACTS OF GOD}

The collision clause of the National Standard Automobile Policy reads: "To pay for direct and accidental loss of or damage to the automobile, hereinafter called loss, caused by collision of the automobile with another object...."1 Since collision means "a violent meeting,", the clause would seem to cover any loss from violent contact with another object, ${ }^{3}$ whether the automobile, the object or both were in motion. Although in defining collision many courts have used so broad a definition, ${ }^{4}$ insurance companies have argued, usually successfully, in favor of excepting collisions caused by falling objects ${ }^{5}$ or acts of God. ${ }^{6}$ This comment will consider the advisability of such exceptions.

1 Quoted in Barnard v. Houston. Fire \& Casualty Ins. Co., 81 So. 2d 132, 134 (La. App., 1955). Consult Faude, Automobile Liability Coverage under the National Standard Automobile Policy, 27 Miss. L. J. 120 (1956), for a brief historical sketch of the standard policy. In a standard policy the language of the analogous parts is uniform but there "[are] no rigid requirements as to sequence or arrangement. . .." Ibid., at 121.

2 Webster's Int'I Dictionary 526 (2d ed., 1947).

${ }^{3}$ In discussing "What Is 'Collision'?" one authority states "that (1) the insured automobile need not be in motion and (2) the collision need not be with another automobile." Fire, Casualty and Surety Bulletins, Cpc-2, Auto (Fire) (4th Printing, 1955). Also consult 5 Appleman, Ins. Law and Practice $\S 3201$ (1941); 13-14 Huddy, Cyclopedia of Automobile Law $\$ 228$ (9th ed., 1931).

4 E.g., Teitelbaum v. St. Louis Fire \& Marine Ins. Co., 296 Ill.App. 327, 329, 15 N.E. 2d 1013,1013 (1938), where the court said, "'[C]ollision' means strictly the impact of objects .. through any one of such objects moving against the other. ..."

5 Jacobs v. Camden Fire Ins. Ass'n, 135 F.Supp. 837 (W.D. Pa., 1955); O'Leary v. St. Paul Fire \& Marine Ins. Co., 196 S.W. 575 (Tex.App., 1917). Contra: Barnard v. Houston Fire \& Casualty Ins. Co., 81 So. $2 d 132$ (La.App., 1955); Teitelbaum v. St. Louis Fire \& Marine 